University of Denver

Digital Commons @ DU

$9-2018$

\title{
Declining Versus Increasing Access to American Aviation Technology: Syria and Saudi Arabia in the 20th Century
}

Andrea L. Stanton

University of Denver, andrea.stanton@du.edu

Follow this and additional works at: https://digitalcommons.du.edu/religious_studies_faculty

Part of the Near Eastern Languages and Societies Commons, and the Science and Technology Studies Commons

\section{Recommended Citation}

Stanton, Andrea L., "Declining Versus Increasing Access to American Aviation Technology: Syria and Saudi Arabia in the 20th Century" (2018). Religious Studies: Faculty Scholarship. 14.

https://digitalcommons.du.edu/religious_studies_faculty/14

This Article is brought to you for free and open access by the Religious Studies at Digital Commons @ DU. It has been accepted for inclusion in Religious Studies: Faculty Scholarship by an authorized administrator of Digital Commons@DU. For more information, please contact jennifer.cox@du.edu,dig-commons@du.edu. 
Declining Versus Increasing Access to American Aviation Technology: Syria and Saudi Arabia in the 20th Century

\section{Publication Statement}

The Version of Record of this manuscript has been published and is available in ASIAN JOURNAL OF MIDDLE EASTERN AND ISLAMIC STUDIES, 28 September 2018, http://www.tandfonline.com/10.1080/ 25765949.2018.1481620 
The Version of Record of this manuscript has been published and is available in ASIAN JOURNAL OF MIDDLE EASTERN AND ISLAMIC STUDIES, 28 September 2018, http://www.tandfonline.com/10.1080/25765949.2018.1481620

\title{
Declining Versus Increasing Access to American Aviation Technology: Syria and Saudi Arabia in the 20th Century
}

Andrea L. Stanton

Department of Religious Studies, Islamic Studies, University of Denver, USA

\begin{abstract}
This article uses Syria and Saudi Arabia as contrasting examples of how different Arab states interacted with United States aviation technology, involving aviation technology companies, airline cor-porations, and government officials as they worked to develop civil and military aviation capabilities after World War II. It consid-ers the role played by airline companies like TWA, the impact of the shift from military to commercial aviation technology among companies like Boeing, and the fallout from regional political developments like the Iranian Revolution. These factors all placed varying constraints on the two countries' ability to draw upon American sources for airplanes and other aviation technology, channeling but not preventing Syrian and Saudi efforts toward aviation development. It suggests that the US government acted as gatekeeper in terms of access to US aviation technology, but that unless strategic concerns prompted its involvement, states like Saudi Arabia primarily interacted with US airline and aviation technology corporations.
\end{abstract}

\section{Introduction}

This article investigates how Middle Eastern states' efforts to build commercial aviation programs intersected with U.S. corporate and government interests - the key sources of the various constraints limiting or channeling their aviation options. It focuses upon two key Arab states, Syria and Saudi Arabia, as case studies, using The Boeing Company archives, T.W.A. corporate publications, U.S. government documents, and newspaper articles and period advertisements. In doing so, it highlights and analyzes the impact of two key developments. First, it considers the important role played by United States institutions in launching Syria's national airline and establishing Saudi Arabia's aviation infrastructure. It examines the 1947 air transportation agreement between the United States and Syria, which established "fifth freedom" carriage rights and a warm bilateral relationship at a time when the Arab League was encouraging a protectionist stance toward non-Arab airlines. Second, it examines the diverging paths each country took with respect to the United States airline originally contracted (and encouraged by the US State Department) to assist its own national airline's devel-opment: Pan American in Syria, and TWA in Saudi Arabia. It assesses how Syrian Airways' quick break with PanAm and Saudi Arabian Airlines' 30p years under TWA operation fit into the trajectory of aviation development in each country. As part of this assessment, it considers in particular the impact of Saudi Arabian Airlines' incorp-oration in 1963, which led to both an increasing emphasis on Saudization and also a new operations contract with TWA in 1966. 
Middle East aviation in this period engaged with three main players on the United States side. From the 1940s through the late 1960s, the major two players in Middle East were US airlines and the United States government. US airlines - most notably Pan American and Trans World Airlines (TWA) - began taking on consultancy and operations roles in airlines around the world starting shortly after World War II. In some cases, they were encouraged to do so by State Department officials, although in the Syrian and Saudi cases, the State Department appears to have played a lesser role, and some scholars argue that American government officials primarily worked to limit aviation sales., not to encourage them. ${ }^{1}$ Aviation technology companies like Boeing did sell airplanes to Middle Eastern airlines, but not in substantial numbers until the early 1960s. This delayed engagement seems to have come in part from the govern-mental assumption that all aviation technology was, at least in principle, military. In the early postWorld War II era, no firm lines separated commercial and military avi-ation - not least because most military planes used during the war had been commer-cial planes made over. Further, in a pinch, even jet planes produced to commercial specifications could be used for troop and materiel transport.

As time passed, Cold War concerns surfaced: aviation technology companies were required to obtain export licenses in order to sell airplanes and related items abroad, with the understanding that the purchasing airline- and country, since most sales were to national airlines - would not re-sell them to any Communist or unfriendly nation-states. Export restrictions during the Eisenhower administration allowed sales only to "free world" countries that promised not to resell the planes to Communist or other states unfriendly to the United States. ${ }^{2}$ Yet US governmental fears of commercial aircraft being used for military purposes by hostile governments were minimal com-pared to its concern regarding the sale of military aviation technology, which primarily meant fighter jets and aircraft surveillance technology. A Boeing 727 might be used to transport troops, arms, or other wartime materiel, but a fighter jet or surveillance plane falling by sale or requisition into hostile control posed a much greater threat to US and allied countries' security.

Military aviation products were also important to the companies that produced them. Aviation technology companies like Boeing likely placed less focus on Middle East markets in the immediate post-war years because their corporate identities and primary revenue streams came from military aviation technology. They offered com-mercial airplanes as part of their product lines, but they seem to have been less cen-tral, and certainly not worth major marketing and sales efforts overseas. Only after Boeing introduced the 707 in 1958 did

\footnotetext{
${ }^{1}$ See Jeffrey Engel, Cold War at 30,000 Feet: The Anglo-American Fight for Aviation Supremacy (Cambridge: Harvard University Press, 2007).

${ }^{2}$ Engel's work does not directly address sales to Saudi Arabia, Syria, or Iran.
} 
commercial sales take precedence. As military sales slowed in the $1960 \mathrm{~s}$, and even more as the United States economy stalled in the 1970s, Boeing increased its efforts to sell commercial aircraft to Middle Eastern and other "third world" countries - which by that point had also increased their commer-cial purchasing power.

This article uses Syria and Saudi Arabia as case studies from two different parts of the region, because both had early, aviation-related histories with the United States, and because their trajectories since the mid-1940s have diverged so profoundly. Saudi Arabia's relationship with the United States government remained warm, and as the largest and for much of the past seventy years the wealthiest country in the region, it continued to be a strong customer of U.S. commercial aviation technology. At the same time, Saudi Arabia's sustained alliance with the United States - coupled with the dislocation in U.S. foreign policy that followed the Iranian revolution - enabled it to access military aviation technology as well. Syria's relationship with the United States government, by contrast, decayed as Syria transitioned to a military, Arab socialist government allied in the 1950 s more consistently with Nasserist Egypt than any superpower. At the same time, Syria's smaller population and landmass, coupled with its weaker and more agrarian economic base, made it a less important client to U.S. com-mercial aviation corporations. As a result, Syria never enjoyed the military technology access granted Saudi Arabia, and instead - as relations with the U.S. government deteriorated further in the late 1970s - was placed under various sanctions, limiting its ability to purchase commercial aircraft and replacement parts.

Two moments help illuminate the two countries' divergent histories, highlighting how changes in bilateral government relations as well as corporate relations impacted the kind of modernization that each state could realize with American airlines and avi-ation technology. In focusing on these two moments, this article builds upon earlier scholarship analyzing particular aspects of aviation modernization. Existing literature ranges from older studies of the United States' role in building the Dhahran airfield and the AWACs program, to recent studies like Sean Foley's work on the 1952 hajj air-lift, Jennifer Van Vleck's study of Pan American's work with Afghanistan's Ariana Airline in the late 1950s, and Yoav Di-Capua's assessment of the interplay between aviation, class, and modernity operating in early mid 20th century Egypt, as well as Jeffrey Engel's work on what he terms the British-U.S. "fight for aviation supremacy" during the early Cold War. ${ }^{3}$ This study seeks to build upon the historical examinations made regarding aviation modernization in the Middle East, and to further explore the kind of modernization and modernity - developing in each country, as well as the impact of external (American) constraints. In doing so, it also hopes to highlight the diverse approaches to both that characterized states in the Middle East. While part of one region, these states each followed separate paths, reflecting their own particular cir-cumstances and the specific concerns of their leadership.

\footnotetext{
3 Sean Foley, 'Airlift for Allah: The United States and the 1952 Hajj', paper presented at 'America and the Middle East' Conference, American University of Beirut, January 2010. See also Jennifer Van Vleck, 'An Airline at the Crossroads of the World: Ariana Afghan Airlines, Modernization, and the Global Cold War', History and Technology 25(1), (2009), pp. 3-24, and Yoav Di-Capua, 'Common Skies Divided Horizons: Aviation, Class, and Modernity in Early Twentieth Century Egypt', Journal of Social History (2008), 917-942.
} 


\section{Syria: From International Air Transport Agreement to Military Control}

Syria became in 1947 one of the first Arab countries to ratify a bilateral air transport agreement with the United States. The agreement allowed Syrian planes to land and take off from American airports, and vice versa. Carrier agreements required complex negotiations between national governments, were generally undertaken on a bilateral basis, and required approval both for the two countries' airplanes to make round trips between them, and also for each to uphold the "fifth freedom" right for carriers to use the other country's airports as transit stops for travel to third countries. ${ }^{4}$ (In this case, the agreement specified route options for the United States and noted that Syrian transit stops would be specified at a future date. ${ }^{5}$ ) Reaching a carrier agreement was a time-consuming process, complicated in this case by Arab League efforts to encourage member states to privilege Arab-state airlines, which undercut the mutuality of bilateral agreements with non-Arab countries.

Founded in 1944, the Arab League had developed its own template for bilateral air transport agreements, which George Brownell, a New York lawyer who negotiated various United States aviation agreements, described as placing "severe restrictions on operations by foreign air lines within the Arab area", creating a monopoly within the Arab world." ${ }^{2}$ Syria, like its neighbor Iraq, initially appeared ready to insist on an agree-ment in line with the Arab League's model. (Egypt also conducted carrier negotiations with the United States in this period, requiring more protracted and contested nego-tiations, adding to the tensions.) However, Pan Am in early 1947 threatened to overfly Syria and Iraq on its Middle Eastern routes, leaving them with no access to its import-ant Karachi route, which connected the region to South, Central, and East Asia. Iraq responded with a one-year bilateral carrier agreement; Syria responded with a full air transport agreement, signed in April. ${ }^{7}$ The 1947 air transportation agreement between the United States and Syria established bilateral and "fifth freedom" carriage rights, and marked a break with the Arab League's protectionist stance toward non-Arab air-lines. The Syrian agreement was described by contemporaries as a model agreement that should be emulated elsewhere.

\section{Military Involvement}

Syria's introduction to commercial aviation also illustrated another pattern common to the region: the important roles played by the United States military - and national militaries - and US airlines in getting Middle Eastern airlines off the ground. For Middle Eastern airlines starting up in the late 1940s, the U.S. military was often the source of their first planes. Syrian Airways began its operations with two C-47s, military versions of Douglas' DC-3 commercial transport plane designed to carry troops or cargo.

\footnotetext{
${ }^{4}$ The principle of bilateralism was established at the 1944 Chicago Convention on International Civil Aviation, which also led to the creation of the United Nations-affiliated International Civil Aviation Organization. 'Fifth freedom' rights - referencing the idea of the freedom of the skies - were also established at the Chicago Convention, but were first actualized in the 1946 'Bermuda Agreement' signed between the United States and Great Britain.

'Air Transport Agreement Between the United States and Syria', British Institute of International and Comparative Law 1 (2), (1947), 289-293.

${ }^{6}$ George Brownell, 'American Aviation in the Middle East', Middle East Journal 1, (1947), 401-416.

7lbid., 408.
} 
Nor were airplanes its only purchase. Syrian Airways also bought communications and ground support equipment from the US military. ${ }^{8}$ Both purchases were brokered by Pan American, which had an operating contract to run Syrian Airways. The same situ-ation was true in Saudi Arabia. The well-known story is that Saudi Arabia's introduction to aviation began with the DC-3 that President Franklin Roosevelt gave Ibn Saud after their meeting in 1945, with a rotating throne installed so that the king could always face Mecca. ${ }^{9}$ While likely not the direct result of FDR's state gift, in 1946 the monarchy asked Trans World Airlines (TWA) to purchase more airplanes, which would form the core of a new Saudi Arabian airline. The US Army Corps of Engineers began con-structing the Dhahran airfield, operating under a 1945 agreement that originally required the US to turn operations over to the Saudis in 1949, although the agreement was extended. ${ }^{10}$ Like Syrian Airways, Saudi Arabian Airlines' first fleet was made up of five military transport planes, all DC-3s, which TWA had purchased from the U.S. military.

These two early developments - the bilateral air transport agreements and the important roles of the United States military and US airlines - set the tone for Middle Eastern countries engaging in commercial aviation. The US military and the State Department receded as active players in the aviation field, but their concerns about military aviation technology and military uses of commercial aviation tech-nology - remained factors influencing aircraft sales. At the same time, while Middle Eastern airlines flew planes produced by aviation technology companies like Boeing and McDonnell-Douglas, these companies made little effort until the 1960 s to market their aircraft in the region. The major players in this period were the two United States airlines with operating contracts around the region: Pan Am and TWA. They guided the development of Middle Eastern airlines abroad, overseeing purchase and training decisions that kept these airlines closely connected with the United States.

The importance of these latter factors might best be illustrated by Syria's next move. Financially, these new airlines were far from profitable. Technically, administra-tively, and operationally, they had few options for genuine corporate viability. Some lacked adequately trained employees. Most airlines, like Saudi Arabian Airlines, renewed the start-up operations contracts signed with Pan Am and TWA, relying on foreigners (US nationals) to serve as pilots, technicians, and company administrators. Others, like Syrian Airways, turned to even tighter government control. After the 1947 United Nations vote that supported the partition of Mandate Palestine into Jewish and Palestinian territories, resulting in a deep shift in Syrian popular opinion, against the United States. In February 1948, the Syrian government informed US officials that it would not approved Tapline, an American effort to build an above-ground oil pipeline from Saudi Arabia across the Levant to the Lebanese port of Saida. In April, the United States citizens working on the Pan American contract for Syrian Airways ceased work, 8 bid.

${ }^{9}$ See 'US Army Corps of Engineers in Saudi Arabia - Laying the Foundation: Roosevelt meets King Abdul Aziz [Ibn Saud]', Nathan Herring, 4.15.2014, https://www.army.mil/article/124038/US_Army_Corps_of_Engineers_in_Saudi_ Arabia__Laying_the_Foundation_Roosevelt_meets_King_Abdul_Aziz

${ }^{10}$ 'Policy Statement Prepared in the Department of State', 2.5.1951, Foreign Relations of the United States, 1951. The Near East and Africa, Volume 5. File 611.86A/2-551. 
effectively shuttering Syrian Airways' operations. ${ }^{11}$ The end of the Pan American con-tract followed a rough year for its operations in the region: in June 1947, a Pan American flight traveling from Karachi to Istanbul crashed in eastern Syria, near a small Euphrates town called Mayadin. Eight passengers and seven crew members died: 15 of the 36 on board. ${ }^{12}$ While not directly connected to Pan American's Syrian Airways contract, it was Syrian Airways planes that were sent to rescue the survivors and trans-port the injured to Beirut for treatment. The 1948 antagonism between Syria and the United States, which was exacerbated by the creation of the state of Israel and its rec-ognition by the US government, brought an end to Pan American's operations con-tract (although Pan American Airlines appears to have continued operating its own flights through and over Syria). For the next three years, its operations were described as "irregular". ${ }^{13}$

By the early 1950s, Syrian Airways had come under the direct control of the country's air force and was entirely government owned. Just as American commercial airlines brought their own concerns to Middle Eastern airline management, so did the Syrian military. A 1957 report noted that Syrian Airways had "concentrated more on building the internal air routes, from Damascus to Lataqia, Aleppo, and Qamishli, than on international operations" understandable, since a strong domestic transportation network would be of greater use if Syria were under attack. Similarly, the report noted that Syrian Airways could not be considered a commercial enterprise: "it is staffed, except for pilots and some mechanics, by Syrian Air Force personnel, who are answer-able to the chain of command." Nor was the airline required to be financially self-sup-porting: "Expense items like new aircraft, fuel, parts, and hangar facilities come out of the Syrian military budget," while its Air Force management priced domestic fares to compete with bus and other "surface" travel fares. ${ }^{14}$ Syrian Airways did benefit from hajj season travel, flying Iraqi and Iranian pilgrims who came to Damascus for ziyarat (pious visits to the shrines of members of the Prophet Muhammad's family and other Muslim notables) and continued to Mecca for the hajj, but it is unclear what positive financial impact this travel might have had. Turning away from US airlines running Syrian Airways' operations in favor of military control reflected the internal shifts in Syrian governance. ${ }^{15}$ It also set Syria's commercial aviation on a different path from Saudi Arabia and other Middle Eastern countries that continued or renewed their operations contract. The turn to nationalization and military control set Syria on a dif-ferent course, one far removed from American corporate connections, and put Syria long-term in a different category for access to United States commercial and military aviation technology.

\footnotetext{
${ }^{11}$ Farid Abboud, Through Warped Lenses: A History of United States-Syrian Relations, 1945-1954, doctoral dissertation, (Los Angeles: University of California, 1994). ProQuest Dissertations Publishing.

12‘U.S. Plane Smash in Syria Kills 15’, New York Times, 6(20), (1947), p. 4.

${ }^{13}$ Keith Williams, 'Commercial Aviation in Arab States: The Pattern of Control', Middle East Journal 11 (2), (1957), pp. 123-138,

${ }^{14}$ Williams, 131.

${ }^{15}$ See for example Malik Mufti, Sovereign Creations: Pan-Arabism and Political Order in Syria and Iraq (Ithaca: Cornell University Press, 1996) and Patrick Seale, The Struggle for Syria: A Study of Post-War Arab Politics, 1945-1958 (London/New York: Oxford University Press, 1965).
} 


\section{Saudi Arabia: Long-Term Operations Support, with Ongoing Purchases}

The Middle East was not the only region in which US airlines had become heavily involved. In the post war period, collaboration between airlines - whether in the form of operations consultancies, contracts, or outright stock purchases - was not unusual in this period. A 1951 piece on "international airlines collaboration" in the Journal of Air Law and Commerce described the world's airlines as having "develop[ed] a number of interesting and varied relationships". Most of these were unidirectional, involving the 'big four' United States airlines or the major Western European carriers investing in or managing the smaller (and often government subsidized) airlines of the Middle East, South Asia, and Latin America. The article cited TWA's management contract with Saudi Arabian airlines as an example of "simple" collaboration, noting that TWA also "had investments of between $10 \%$ and $40 \%$ in seven other [foreign airlines]." 16 Management contracts and stock investment allowed the contracted or investing air-line to be involved in decisions regarding its partner's operations, while also providing fee, wage, or dividend revenues. ${ }^{17}$

In the late 1940s, US airlines were some of the most corporate airlines in the world, in terms of financial and administrative independence from their national govern-ments. Largely selfsufficient, they were well positioned to consider and implement investment and contractual decisions regarding foreign carriers. In this, they initially enjoyed considerable support from the U.S. government, and particularly the State Department. As Van Vleck has shown in the case of Afghanistan's Ariana Airlines, US governmental support for American airline investments abroad was seen as a means of countering Soviet influence. Hence the government encouraged Pan American, which despite its failed efforts in Syria had successful investment projects in Pakistan, Thailand, and Turkey, to purchase $49 \%$ of Ariana's shares - which it did in April 1957. ${ }^{18}$ This support seems to have been similar, if more rudimentary, in the case of Saudi Arabia, whose aviation story began a decade earlier. A May 1946 confidential note from the US Legation in Saudi Arabia to the Saudi Ministry for Foreign Affairs noted: "The Ministry will recall that TWA is the aviation company chosen, insofar as the American Government is concerned, to operate air line travel in this area of the Middle East.," ${ }^{19}$ in large part because it had been the only US airline permitted by the US' Civil Aeronautics Board to land in Dhahran. ${ }^{20}$ However, State Department interest appears to have diminished and largely disappeared by the early 1950s; TWA's work in Saudi Arabia appears in diplomatic correspondence and reports only in lists of US corporations doing work there. ${ }^{21}$

\footnotetext{
${ }^{16}$ Walter Wager, 'International Airline Collaboration in Traffic Pools, Rate-Fixing, and Joint Management Agreements', Journal of Air Law and Commerce 18 (1951), 192-199. In this early post-war period, some continental European airlines were also under American or British airlines' control - including Italy's Alitalia and L.A.I.

${ }^{17}$ Wager, 'International Airline Collaboration', 199.

${ }^{18}$ Van Vleck, 12-14.

${ }^{19}$ Legation in Saudi Arabia to the Saudi Arabian Ministry for Foreign Affairs, 5.29.1946, Foreign Relations of the United States, 1946, The Near East and Africa. Volume VII. File: 890F.796/6-2046.

${ }^{20}$ 'Acting Secretary of State to the Minister in Saudi Arabia' 8.4.1945, Foreign Relations of the United States: Diplomatic Papers, 1945. The Near East and Africa, Volume 8. File 890F.248/8-445.

${ }^{21}$ See for example Memorandum by the Civil Air Attache for the Middle East to the Officer in Charge of LebanonSyria Affairs, 12.15.1954, Foreign Relations of the United States, 1952-1954, General: Economic and Political Matters. Volume 1, Part I. File E/TRC/AV, lot 59 D 206.
} 
Like Syria, Saudi Arabia's entrée into the world of airline companies began almost immediately after World War II ended. Unlike Syria, Saudi Arabia had been a sovereign nation since 1932, with a growing oil economy following its official dis-covery in 1938. TWA's relationship with Saudi Arabia had begun not with its national airline but with the king's personal airplanes, which it flew and maintained, operating primarily out of its Cairo offices. In 1946, TWA accepted a contract to operate the newly formed national airline and provide technical assistance. TWA's American pilots flew Saudi Arabian Airlines (then known as SDI) airplanes, and since none of these pilots were Muslim, flight paths out of Jeddah and Ta'if were care-fully arranged to keep the planes far from Mecca and Medina. ${ }^{22}$ TWA mechanics maintained and serviced the airplanes, while TWA ground personnel managed the airfields at Dhahran and elsewhere around the country. Much of this activity was covered in the TWA Skyliner - the airline's then-weekly newspaper, published for TWA employees - helping build awareness of TWA's Saudi Arabian activities among company employees.

The Saudi airline fleet expanded regularly in its first few years: ten DC-3s by 1948, 15 DC-3s and five Bristol 170s in 1949, with four DC-4s purchased in 1952, to permit longer-range,

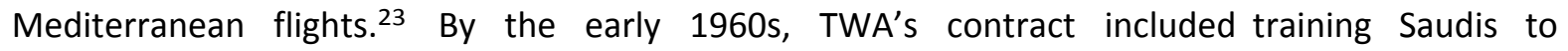
pilot the Boeing 720Bs that SDI purchased in early 1962. Pilots trained at TWA's Flight Training Center in Kansas City ${ }^{24}$, as did Saudi maintenance per-sonnel, and by 1965 at least one Saudi pilot was flying. Captain Nahar Nassar, born in 1935 in Al Khobar, was mentioned in TWA and Boeing documents, as both the first Saudi commercial airplane pilot and also pilot of one of King Faisal's private air-planes. ${ }^{25}$ He had begun as a messenger for Aramco in Dhahran, and was ultimately sent to Egypt to study at its Misrair (Egypt Air) Flying Institute. After obtaining his pri-vate and commercial license, he continued to an academic year at the flight institute in Southampton, England. He obtained his instrument rating in 1957 and served as co-pilot and captain on SDI flights, finally obtaining the FAA's Air Transport Rating in $1960 .^{26}$

TWA lauded Nahar's example as an early sign of 'Saudization' but continued placing employment ads for its Saudi-based operations in the New York Times and other newspapers through the mid 1960s. Most advertisements were for flight engineers and instrument mechanics, aimed at filling one or a small number of positions, and appeared only intermittently. However, in October 1965, TWA placed a much larger employment ad, looking for captains, flight engineers, ground school instructors, flight instructors, aircraft mechanics, power plant jet engine mechanics, piston engine mechanics, hydraulics experts, sheet metal workers, line and hangar mechanics, plating experts, air conditioning repairmen, and electricians. The positions required considerable professional experience and, for most, FAA certification. ${ }^{27}$ These ads testify to SDI's plans to expand its

\footnotetext{
${ }^{22}$ 'From Flying Carpets to DC-3s ... Arabian Desert Goes Modern', Skyliner 1.8.48, p. 4-5. While this article's title drew upon 'Arabian Nights' imagery, subsequent Skyliner articles on Saudi Arabia had more prosaic titles.

${ }^{23}$ 'Saudi Arabian Airlines: The Jewel of the Middle East', Aero Magazine 1(2), (1998), page numbers. Aero is published by The Boeing Company.

24'Jet Training Program', Skyliner 1.15.62, p. 2.

${ }^{25}$ 'Saudi Crews Praise TWA After MCl Jet Overhaul', Skyliner 3.1.65, p. 3.

${ }^{26}$ Daniel Da Cruz, 'Horatio Ali, Jr.: The Story of Nahar Nassar', Aramco World July/August 1969, 28-36.

${ }^{27}$ In comparison to other airplane-related ads, the TWA ads were more elaborate, with more text and with words fully written out rather than abbreviated. They also specified salary and benefits. In other words, the ads were likely more expensive than most of the others on the page, and they stood out.
} 
operations, but also indicated how far the airline still was from being able to meet its employment needs by hiring Saudi nationals.

In principle, the TWA contract was intended to be short-term, enabling Saudi nationals to take over the airline's management and operations. However, in November 1966, TWA and SDI signed a new, broader operations management con-tract. By this time, Saudi Arabian Airlines had been operating for twenty years. The Saudi state was enjoying increasing oil revenues, and the power struggle between the aged King Saud and Crown Prince Faisal had ended with Faisal taking the throne. Yet instead of taking control of the national airline, the Saudi monarchy - which subsi-dized and at least indirectly controlled SDI - turned it further over to TWA. The new contract expanded TWA's responsibilities, especially TWA's engagement with non-tech-nical aspects of the airline - denoted as "finance, sales, and industrial relations". National control remained the ultimate goal, but appeared further off in the future. ${ }^{28}$

TWA's new contract with Saudi Arabia was not the only management contract that the company had active in the mid-1960s. TWA also revised and expanded its long-standing contract with Ethiopian Airlines in 1966, while continuing its operations con-tract with Trans Mediterranean Airways and its technical services contracts with Swissair, Delta, Cathay Pacific, and Alaskan. In its corporate communications, TWA emphasized both the increased responsibilities of the new contract with SDI and also the fact that its ultimate goal was for TWA to empower Saudi nationals to run Saudi Arabian Airlines. The new contract also seems to have pushed TWA to consider its work with Saudi Arabia an upper management, rather than middle manage-ment, concern.

\section{TWA Company Coverage of Its Saudi Operations}

Historically, the TWA employees who managed TWA's operations in Saudi Arabia were mid-level managers - as was the first major appointment under the new contract: John Gaiser. Previously the director of airframe overhaul, Gaiser in March 1967 became system general manager of TWA's Saudi operations and Saudi Arabian Airline's assist-ant director general. (The director general was always a Saudi national. $)^{29}$ While many of Gaiser's direct reports were continuing TWA employees, his deputy general man-ager for training was a new TWA hire, previously superintendent of the Prairie City, lowa school district. When Gaiser returned to the United States in 1969, his replace-ment in Saudi Arabia was a TWA executive: Mel Milligan, a company vice president and its general counsel. The company's senior vice president for external affairs, Edwin Smart, said that TWA's increased responsibilities with SDI had convinced him "that an appropriate successor for John Gaiser would have to be sought at senior TWA management levels." ${ }^{30}$ Elevating the stature of the TWA personnel assigned to head TWA's operations in Saudi Arabia was an important step.

\footnotetext{
${ }^{28}$ 'Gaiser Appointed to Top Saudi Job', Skyliner 3.13.67, p. 1.

29'Gaiser Appointed'.

${ }^{30}$ 'Winning Friends or Winning Routes, External Affairs Plays Vital Role', Skyliner 7.14.69, p. 4. 31'Editor's Notes', Skyliner 2.1.65, p. 2.
} 
The new contract also increased the number of TWA employees working in Saudi Arabia. In early 1965, the company had just over 150 employees - nearly evenly div-ided between pilots and flight engineers and maintenance and transportation work-ers. ${ }^{31}$ Just after the new contract took effect in November 1966, TWA reported 200 employees in Saudi Arabia with an expected increase to 300. By mid 1969, the com-pany had 330 employees in Saudi Arabia - just over one for every 100 of the 3,000 Saudis or third country nationals employed by the airline. This was a tiny percentage of TWA's overall employee base, which was growing rapidly in the 1960s, but a signifi-cant percentage increase in its Saudi-based staff. With most TWA employees staying in Saudi Arabia for two to three years, this meant that over a 10 -year period, 1,000-1,500 employees, or between 5 and 10\% of total company employees, might have had dir-ect experience living and working in Saudi Arabia.

Its difficult to measure the impact of these overseas work stints. For some employ-ees, the Saudi experience might have been quite negative; for others, it might have been positive or even a non-event. But TWA's Saudi-based employees received ongoing coverage in its employee publication: the Skyliner. The Skyliner's articles tracked the life events of TWA personnel in KSA, the appointments of mid-level and senior-level managers, and engagement in leisure activities like baseball. It provided a vivid sense of aviation developments within the Middle East - and its articles focused almost exclusively on Saudi Arabia. Its employee updates included transfers to and from Saudi Arabia and reported on births or employment milestones of TWA employ-ees stationed there. Its interviews with upper level management figures often touched on TWA's international operations contracts, and particularly on its contract with Saudi Arabian Airlines. Yet the Skyliner's perspective was limited: although Saudi Arabian and other Arab TWA employees or affiliates appeared in photos and when mentioned by name in interviews, the Skyliner did not quote or interview them. Its focus was on American employees.

In addition to whatever capillary connections were fostered by TWA employees living abroad and SDI Saudi nationals who came to Kansas City for training, TWA's continued connection to Saudi Arabian Airlines gave much of Saudi aviation an American face and an American voice. Further, the TWA contract kept Saudi aviation tied much more closely to the United States and to American corporations, in terms of management style, aircraft purchases, corporate strategy, and more. TWA's work for Saudi Arabian Airlines meant that it was heavily involved in the shift in hajj transport: from the steamships of the early 20th century to the airplane travel of the post-World War II era. In 1968, a Columbus-based customer service agent named Bob Horton described his work in Saudi Arabia in 1960, where he served as senior sales represen-tative. "[I was] coordinating air movements of Moslems on their pilgrimage to Mecca during the Haj", he told the TWA Skyliner, continuing a modern tradition of non-Muslim transport staff supporting Muslim pilgrimage travel. ${ }^{32}$

${ }^{32}$ ‘Bob’s Passport's a Diary; He Could Write a Book!', TWA Skyliner, 10.21.1968, p. 6. 
The story of Saudi Arabia is shot through with American influences, coming through the public and private sectors, as well as through direct governmental and military contacts. For the purposes of this article, the most important point about the Saudi aviation story and its US connections is how different it was from Syria's aviation development. However minor the capillary connections, how-ever small TWA's impact in terms of management training or purchasing decisions, they far exceeded the negligible direct American influence in Syria - a reminder of the two countries' continuing diverging paths. More broadly, these diverging paths highlight the need to recognize that there is no one universal story of Middle Eastern countries and aviation modernization, particularly when it comes to the crucial issue of their interaction with the superpowers who possessed avi-ation technology.

\section{Shifts in Access After the Iranian Revolution}

While TWA and Pan American had been intimately engaged in Saudi Arabia and elsewhere around the region since the post-World War II period, the major aviation technology companies - like Boeing and McDonnell-Douglas - did not begin sell-ing airplanes in earnest to Middle Eastern airlines until the mid 1960s. The 1970s brought an increasing interest in selling commercial and military aviation technol-ogy to Middle Eastern countries - including major sales to Iraq and proposed sales to Libya. These new opportunities required companies to have a commensurately increasing presence in the Middle East: Boeing opened new offices in Saudi Arabia and developed marketing research to countries like Saudi Arabia. Their work pri-marily focused on the technical specifications of the technology and the cost and other efficiencies that new purchases would bring. For example, 1970s Boeing pres-entation decks made for Middle Eastern airlines looking to purchase various 747 models focused almost exclusively on the plane's technical specifications. Of the twenty-plus pages that made up each deck, only two or three included text or graphics referring specifically to the purchasing airline and its fleet, routes, or other concerns. Instead, they focused generically on the cost and time savings that an airline would enjoy by purchasing another Boeing airplane, because some percent-age of parts would be interchangeable with those that an airline might already own, and whose repair a mechanic familiar with other Boeing airplanes could undertake without requiring much new training.

Similarly, Boeing's presentation decks emphasized that pilots already trained on other Boeing airplanes could easily transition to a 747. The text of speeches delivered at airplane handover ceremonies held at Boeing's Everett hangar also reflected Boeing's product focus. While Saudis present were thanked by name, Boeing officials generally focused their remarks on the qualities of the airplanes being delivered - or, in some cases, on the qualities of other planes in Boeing's production line. For example, the draft of a speech given at a July 1985 delivery ceremony praised Saudi Arabian Airlines for choosing the 747: "We must recognize ... the ability of Saudi Arabian Airlines to project their requirements into the future and to have selected the 747-300 with its unique capabilities for those future 
needs", said Everette Webb, a Boeing vice-president and one of the $747 \mathrm{~s}$ designers. ${ }^{33}$

At the same time, aviation companies like Boeing began putting increasing emphasis on selling military aviation technology to the Middle East - an effort encour-aged and facilitated by various U.S. government departments, most notably the State Department. State Department interest was particularly focused on sales to new state clients: the Foreign Relations of the United States documents show no discussion of Boeing sales to Saudi Arabia, but they include numerous telegrams and other corres-pondence about planned sales to Iraq, Libya, Egypt, and Yemen. ${ }^{34}$ At times, these efforts appear to have exceeded the bounds of acceptable U.S. business practice - as when Boeing and other companies faced allegations of bribery and kickbacks in 1978, leading to a round of S.E.C. investigations. While these marketing and sales efforts included Saudi Arabia, their primary focus, as in previous decades, was Iran. This changed after the Iranian Revolution of 1979. Since the 1940s, Iran had enjoyed the lion's share of US military and State Department support in the Middle East, second only to Israel. Iran's military benefited not only from military training and support, but also from some of the earliest government approvals (and corporate initiatives) for the purchase of military aircraft. As a result of the close connection with Iran, and due to regional geo-political concerns, United States officials appear to have had little interest in expanding military technology privileges to Arab countries. However, the situation changed dramatically after the 1979 Iranian Revolution. Almost overnight, Saudi Arabia took its place as the United States' second most important regional partner, which impacted aviation technology companies as well.

The Boeing Company had been selling commercial jet planes to Saudi Arabia since 1962, when Saudi Arabian Airlines purchased several 720bs. By the 1970s, Boeing was selling $747 \mathrm{~s}$ to SDI and smaller jets for private use. In the late 1970s, Boeing was among several corporations investigated by the Securities and Exchange Commission (SEC) for both putting Saudi officials on their payrolls and for paying kickback fees. However, the loss of Iran as an aviation client and the new US governmental interest on Saudi Arabia seems to have encouraged a new focus on Saudi Arabia - for com-mercial and military purchases. The Boeing corporate archives include two major stud-ies of Saudi Arabia produced in early 1981 for company use. One, titled "Saudi Arabia: An Overview of its Decision Making Process", was a 30-plus page report written by Devol Brett, a retired US Air Force officer. The other was an in-house brief of similar length, prepared for Boeing Company Chairman and CEO Thornton Wilson. The first report began by comparing Saudi Arabia and Iran.

"The fall of the Shah of Iran and the subsequent disastrous disorder in every sector of the society has resulted in numerous critical appraisals", the report's executive sum-mary noted, referring to corporate concerns that Saudi Arabia would be the next country to face an internal coup. "Most attempt to compare Iran and Saudi Arabia," it continued, "with the conclusions of the more strident being that Saudi Arabia is headed in the same direction as Iran and with the speed of sound."

${ }^{33}$ The Boeing Company Corporate Archives, 3412/35.

${ }^{34}$ See for example 'Telegram from the Interests Section in Baghdad to the Department of State', 3.31.1973, Foreign Relations of the United States, 1969-1976, Iran, Iraq. 27, p. 607. 
However, it noted, "our conclusions indicate that Saudi Arabia is highly unlikely to follow the Iranian path and is not in the near term vulnerable to either an internal or external threat."35 These were judicious concerns. From a corporate perspective, the Iranian Revolution meant an expensive loss - including the time and effort expended cultivating contacts, hiring agents, and building revenue streams. After the Iranian Revolution, one key question for aviation and other corporations involved in the Middle East would reasonably have been: is this market worth the effort?

Interestingly, the report on Saudi decision-making focused exclusively on commer-cial aviation - analyzing the current situation in Saudi Arabia and assessing future opportunities. While the second report, the in-house brief, looked at both commercial and military opportunities, it also focused on the commercial side, with diagrams sketching SDI's projected fleet requirements and a list of the Boeing jets that SDI owned or had on order. Boeing's military initiatives were relegated to the "Summary of Boeing Activities in Saudi Arabia" section, which included proposed military aircraft sales and a "vehicle locating system". These were sandwiched in with other items, such as the two asphalt plants that Boeing operated with Aramco and the data proc-essing services that it offered through its International Construction Services division. ${ }^{36}$ The other military initiative mentioned was one being handled directly by the US Air Force's Foreign Military Sales program - that of selling Boeing's Airborne Warning and Control System surveillance technology, better known as AWACS, to the Saudi government.

The Boeing report was released in March 1981. The following month, President Reagan announced his support for the AWACS sale, which at the time was the largest foreign arms sale in US history. "As a part of Saudi military modernization plans, as well as to complement the purchase of the F-15 in 1978, Saudi Arabia and the United States negotiated the America-Saudi Air Defense Enhancement Package in 1981," which centered around the sales, operational training, maintenance, and logistics sup-port for five E-3A AWACS aircraft, at the time the most sophisticated "early warning detection system" in the world, as Miglietta noted. ${ }^{37}$ The proposal sparked intense debate in Congress and beyond that lasted well over a year, in part because of con-cerns over Saudi intent toward Israel, and in part because a previous, late 1970s pro-posal to sell the same package to Iran, ended with the Iranian Revolution. Critics expressed concern about the wisdom of selling such powerful defense equipment to a government that might, like the shah's, collapse and be replaced by a hostile one. In the end, the sale was approved and Saudi Arabia

${ }^{35}$ Devol Brett, Saudi Arabia: An Overview of its Decision Making Processes, date penciled in as "March 1981 (?), The Boeing Company Corporate Archive, File Name "Saudi Arabia".

${ }^{36}$ Saudi Arabia Brief, handwritten note indicating date as March 1981 and author as D.J. Olson. The Boeing Company Corporate Archive, File Name "Saudi Arabia".

${ }^{37}$ See John P. Miglietta, American Alliance Policy in the Middle East, 1945-1992: Iran, Israel, and Saudi Arabia (Lanham, MA: Lexington Books, 2002). 
took Iran's place as the United States' second major ally in the Middle East. ${ }^{38}$ (It was also an economy booster: the AWACS package totaled $\$ 8.5$ billion, paying for an estimated 130 US military advisors and over 800 US defense corporation employees at companies like Boeing, Westinghouse, and General Electric.) $)^{39}$ This approval opened the door for subsequent aviation military technology purchases - including an October 2017 Department of Defense authorization for a $\$ 240$ million Boeing contract to update Saudi Arabia's AWACS system. Even at that point, Saudi Arabia remained the sole Middle East country - and the only country outside North America and Europe - authorized to operate AWACS technology..$^{40}$

\section{Conclusion}

The AWACS story is well known, but here it is relevant for two primary reasons. First, geo-political concerns made selling commercial and military aviation technology in the Middle East more challenging: concerns over potential regime change in Saudi Arabia - which seemed more likely given the recent Iranian Revolution - joined with worries about jeopardizing Israel's security, making lobbyists, government officials, members of Congress, and even Boeing officials hesitant to approve the AWACS sale. Second, it is a reminder that the story of aviation development in the Middle East, including Saudi Arabia, unfolded under a particular set of constraints, and often in close connec-tion to the United States. These constraints included the fact that countries like Saudi Arabia were buying rather than developing aviation technology, putting them in a passive or dependent position, and that aviation technology, because of the blurry lines separating commercial from military air power, had become closely caught up in Cold War politics. Syria and Saudi Arabia's aviation modernity narratives connected them in different ways with United States governmental and corporate interests. These produced one set of operational constraints, but so did another: the presence of Iran. Its removal after the 1979 revolution enabled Saudi Arabia to become much more important to US strategic interests - which translated into greater support for Saudi purchases of military aviation technology, and a renewed interest from compa-nies like Boeing.

The AWACS story also highlights the impact of the divergent paths taken by Syria and Saudi Arabia. By the time that Saudi Arabia received approval for the AWACS pur-chase, Syria hadalready been designated a state sponsor of terrorism, severely curtail-ing its ability to buy any aviation technology, including spare parts, from the United States or its allies.

\footnotetext{
${ }^{38}$ For an overview of the AWACS sale, see Nicholas Laham, Selling AWACS to Saudi Arabia: The Reagan Administration and the Balancing of America's Competing Interests in the Middle East (Westport: Praeger Publishers, 2002). This event has drawn particular interest from political scientists studying interest groups' impact on Congressional activities. See for example Daniel Price, 'Presidential Power as a Domestic Constraint on Foreign Policy: Case Studies Examining Arms Sales to Saudi Arabia’, Presidential Studies Quarterly 26(4), (1996), 1099-1113.

${ }^{39}$ Miglietta, 238.

${ }^{40}$ See Fergus Kelly, 'Boeing wins $\$ 240$ million Saudi Air Force AWACS modernization contract', The Defense Post, 10.16.2017, https://thedefensepost.com/2017/10/16/boeing-saudi-awacs-contract-240-million/. Last accessed 4.15.18.
} 
The last Boeing Company material to mention Syrian aircraft were a January 1976 presentation deck for a Syrian Arab Airlines 747SP and a March 1977 report on how the 747SP was performing in Syrian service. ${ }^{41}$ From its warm initial rela-tionship with the United States in 1946 and 1947, Syria's increasingly distant position from US corporate and governmental interests meant that by the early 1980 s its avi-ation story differed in almost every respect from Saudi Arabia's. Both countries successfully developed civil and military aviation programs, but their profiles with respect to US aviation technology, commercial and military, bore little connection to one another. While Saudi Arabia became increasingly central to the US government's strategic and military interests, and became increasingly important to aviation compa-nies like Boeing, Syria - in part by its early choice - became important to none.

Finally, what the story of Saudi Arabia's aviation development highlights is not only that its relationship with the United States was close. It highlights that the relationship was a threepart one, and that only one of those parts involved the US government. The US government, represented primarily by State Department officials, exhibited concern or interest about Saudi access to US aviation technology primarily in the late stages and immediate aftermath of World War II, and during the AWACS sales process. For most of the intervening decades, Saudi Arabian airlines employees and govern-ment officials interacted directly and primarily with US corporations - most notably, TWA and Boeing. When bilateral tensions or other strategic concerns prompted US governmental involvement, it acted as the primary gatekeeper authorizing or prevent-ing states like Syria and Saudi Arabia from accessing US aviation technology. Otherwise, however, it was US corporations, and their many employees, who served as the faces and the interface bringing US aviation technology and airlines operations to the Middle East.

\footnotetext{
${ }^{41}$ Executive Summary Syrian Arab 747 SP, The Boeing Company Corporate Archive, File 5675/1 and Report on the 747 SP in Service: Pan Am - South African - Iran Air - Syrian Air, The Boeing Company Corporate Archive, File 2895/14.
}

\section{Disclosure}

No potential conflict of interest was reported by the author. 